\title{
Uluslararası Sermaye Hareketliliği İle Sağlanan Yabancı Yatırımcı Oranındaki Değişimin Borsa İstanbul Üzerine Etkisi (The Effect of the Change in the Foreign Investor Ratio Provided by International Capital Mobility on Borsa Istanbul)
}

\section{Murat ATIK (iD) a}

a Milli Savunma Üniversitesi, Kara Harp Okulu, İşletme ve Yönetim Bilimleri Bölümü, Ankara, Türkiye. matik@kho.edu.tr

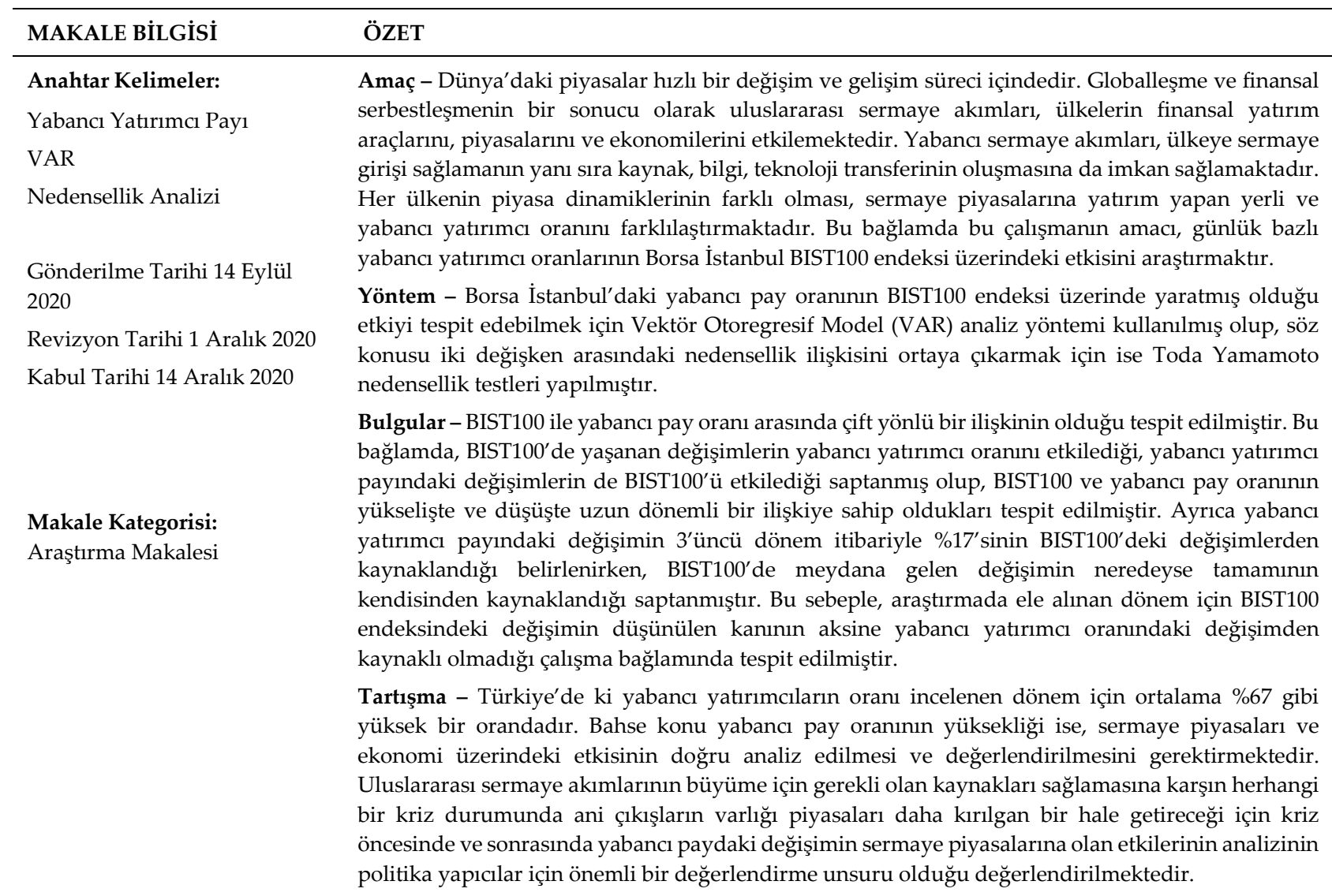

\begin{tabular}{l}
\hline ARTICLE INFO \\
\hline Keywords: \\
Foreign Investor Share \\
VAR \\
Causality Analysis
\end{tabular}

\section{ABSTRACT}

Purpose - Markets in the world are in a rapid change and development process. As a result of globalization and financial liberalization, international capital flows affect countries' financial investment instruments, markets and economies. Foreign capital flows enable the transfer of resources, information and technology as well as capital inflows to the country. The different market dynamics of each country differentiates the rate of domestic and foreign investors investing in capital markets. The purpose of this study is to investigate the effect of daily foreign investor rate on Borsa İstanbul BIST100 index.

Received 14 September 2020

Design/methodology/approach - In order to show the effect of the foreign share ratio in Borsa

Revised 1 December 2020 Istanbul on the BIST100 index, the Vector Autoregressive Model (VAR) analysis were conducted. To reveal the causality relationship between these two variables, Toda Yamamoto causality tests were used.

Accepted 14 December 2020

Findings - It has been determined that there is a two-way relationship between BIST100 and foreign share ratio, changes in BIST100 affect the rate of foreign investors, changes in foreign share affect

Article Classification: BIST100, and BIST100 and foreign share ratio have a long-term relationship in the rise and fall. In addition, while $17 \%$ of the change in the share of foreign investors was due to changes in BIST100

Research Article as of the 3 rd period, it was determined that the change in the BIST100 index for the period examined

\section{Önerilen Atıf/Suggested Citation}

Atik, M. (2020). Uluslararası Sermaye Hareketliliği İle Sağlanan Yabancı Yatırımcı Oranındaki Değişimin Borsa İstanbul Üzerine Etkisi, İşletme Araştırmaları Dergisi, 12 (4), 4097-4112. 
was not due to the change in the rate of foreign investors, as almost all of the change in BIST100 originated from itself.

Discussion - The average proportion of foreign investors in Turkey are as high as $67 \%$ for the period investigated. The high rate of foreign share requires a correct analysis of its effect on capital markets and an accurate assessment of its effects on the economy. Although international capital flows provide the necessary resources for growth, the existence of sudden outflows in the event of a crisis will make the markets more fragile, so the analysis of the effects of the change in foreign shares on the capital markets before and after the crisis can be an important assessment element for policy makers.

\section{GíRİ̧}

Sermaye piyasalarına uluslararası sermaye akımlarının girmesi ülke ekonomilerini etkilemekte olup, ülke içindeki sermayenin artması büyüme için gerekli koşulların oluşmasına da katkı sağlamaktadır. Özellikle ekonomik büyüme arayışı içinde olan ülkelerdeki tasarruf oranlarının yetersizliği firmaların yabancı sermayeye olan ihtiyaçlarını artırmaktadır. Yabancı yatırımcıların finansal piyasalara katılım durumlarının ise piyasaları daha şeffaf hale getirdiği düşünülmektedir.

Ülkelerin sermaye piyasalarına yatırım yapan kişi ve kuruluşları, yabancı ve yerli yatırımcı olmak üzere iki gruba ayırmak mümkündür. Bu bağlamda, yabancı yatırımcıların daha tecrübeli ve bilgili olduğu değerlendirilmektedir. Ayrıca, yabancı yatırımcıların bilgilerini piyasalara aktarmaları durumunun firmalar üzerinde olumlu etki yaratacağı, yabancı yatırımcıların katılımıyla finansal piyasaların daha şeffaf hale gelip kaynakların daha iyi bir şekilde tahsis edilebileceği, piyasalardan elde edilecek bilginin daha kaliteli olacağı ve nihai durumda da daha sağlıklı finansal piyasaların olabileceği ifade edilmektedir (Adabag and Ornelas, 2004:4). Yabancı yatırımciların bahse konu olumlu etkilerinin yanı sıra olumsuz bir takım etkilere de sebebiyet verebilecekleri söylenebilecektir. Bu çerçevede, özellikle kriz dönemlerinde yabancı sermayenin hızlı bir şekilde ülkeyi terk etmesinin ülke ekonomisini daha kırılgan bir hale getireceği ve bu durumun da yaşanan krizin daha da derinleşmesine yol açabileceği değerlendirilmektedir. Uluslararası sermaye hareketlerinin spekülatif nitelikle sermaye hareketlerine dönüşmeye başlaması sebebiyle, yabancı sermaye oranındaki değişimin gelişmekte olan piyasalardaki volatilite ve diğer finansal riskler üzerindeki etkisinin önemli bir konu haline geldiği değerlendirilmektedir. Doğrudan ve uzun vadeli yabancı yatırımların ise sermayenin ülkeyi bir anda terk etmesi mümkün olamayacağı için fiyat istikrarı sağlanması hususunda daha fazla katkı sağlayabileceği kaydedilmektedir.

Bir ülkeden diğer ülkelere çeşitli sebeplerden dolayı hareket eden fonların ne şekilde geldiği ve ne amaçla kullanıldığı önemli bir konudur. Özellikle gelişmekte olan ülkelerin yurt içi tasarruflarının yetersiz olması, ekonomik büyüme ve kalkınma için yabancı kaynaklara başvurmalarını zorunlu hale getirmiştir. Ülkemizde borsada işlem yapan yabancı yatırımcıların 2014-2019 yılları arasındaki ortalamasının \%67,96 gibi yüksek bir oranda gerçekleşmesi durumu, yabancı yatırımcıların sermaye piyasaları üzerindeki etkisinin doğru analiz edilmesini ve ülkenin ekonomik yapısına etkisini doğru anlamayı gerektirmektedir.

\section{ULUSLARARASI SERMAYE HAREKETLERI}

Uluslararası sermaye hareketlerinin açıklanmasına yönelik olarak IMF ve OECD gibi veya farklı kuruluşların öne sürdükleri tanımlamalar olsa da genel anlamda uluslararası sermaye hareketleri, ulusal sınırları aşarak ülkeye giren veya ülkeden çıan fonlara atıfta bulunmaktadır. Bu bağlamda yazında kavrama ilişkin geliştirilen tanımlar birleştirilerek oluşturulan genel ifadeye bağlamında uluslararası sermaye, bir ülkenin karşılığını daha sonra ödemek üzere dış kaynaklardan sağladığı ve ulusal varlıklarını etkileyebileceği mali, teknolojik, bilgisel ve hizmetsel kaynak olarak tanımlanmaktadır (Ekodialog, 2020). Uluslararası sermaye hareketleri özellikle yatırımcıların fon sağlayacağı ülkedeki getiri oranlarına, yatırım koşullarına ve yatım yapmanın kolaylığına göre yön almaktadır. Uluslararası sermaye hareketleri, resmi ve özel nitelikli sermaye hareketleri şeklinde ikiye ayrılmaktadır. Resmi nitelikli sermaye hareketleri, IMF, Dünya Bankası gibi uluslararası kuruluşlar ile hükümetler arasındaki ikili anlaşmalar çerçevesinde gerçekleştirilen kredilerini kapsarken özel nitelikli sermaye hareketleri ise, uluslararası sermaye ve para piyasalarında fon arz ve talep edenlerin yaptıkları işlemleri içermektedir. Bu çerçevede, özel nitelikli yabancı sermaye hareketleri; doğrudan yabancı yatırımları (foreign direct investment), portföy yatırımları (portfolio investment) ve diğer yatırımlar (other investment) olmak üzere üç grupta sınıflandırılmaktadır (Çiftçi, 2015:174). 
Doğrudan yabancı yatırım, bir veya birden fazla uluslararası yatııımcının başka bir ülkede yerli firmalarla ortaklaşa gerçekleştirdikleri, maddi olmayan varlıkların da (teknoloji, marka, teknik bilgi vb.) transferini sağlayan, uzun dönemli ve yatırımcıya yatırımı kontrol etme yetkisini veren yatırımlardır. Doğrudan yabancı yatırımlarda, kısa vadede bazı problemler yaşansa da uzun dönemde hem yatırımcı hem de ev sahibi ülke, söz konusu yatırımlardan kazançlı çıkmaktadır (Kula, 2003:143). İlgili yazında, yirmi altı Afrika ülkesinde yapılan bir çalışmada doğrudan yabancı yatırımların büyüme üzerindeki etkisi PSTR yöntemi ile incelenmiş ve belli bir mali gelişme seviyesine sahip ülkelerde ekonomi üzerinde olumlu gelişmelerin gözlemlendiği tespit edilmiştir (Yeboua, 2019).

Portföy yatırımları ise hisse senedi, tahvil ve doğrudan yabancı yatırımın bir unsuru olmayan banka kredilerine ve borçlanma araçlarına yapılan yatırımlardır. Hisse senetlerine $\% 10$ 'dan az yapılan yatırım portföy yatırımı olarak kabul edilirken, $\% 10^{\prime}$ dan daha fazla yapılan yatırım ise doğrudan yatırım olarak kabul edilmektedir. Buradaki önemli husus ise hisse senetlerinin kontrol amacıyla mı, yoksa yatırım amacıyla mı alınmış olduğudur.

\section{LITERATÜR TARAMASI}

Uluslararası sermaye hareketlerinin etkileri konusunda yazında tam olarak bir fikir birliğine varılamamıştır. Teoride uluslararası sermaye hareketlerinin ülke içindeki sermayenin artmasını sağlayarak finansal piyasaların gelişmesine katkıda bulunduğu ve ekonomik büyüme için önemli katalizör görevi gördügüne yönelik çalışmaların yanı sıra, uluslararası sermaye hareketleri ile büyüme arasında bir ilişkinin olmadığını belirten çalışmalar da bulunmaktadır.

Buna göre, Bekaert ve diğerleri (2005) yaptıkları çalışmada, hisse senedi piyasasındaki serbestleşmenin yıllık reel ekonomik büyümede \%1'lik bir artışa yol açtı̆̆ını tespit etmiştir. Edison ve diğerlerinin ise 2002 yılında gerçekleştirdikleri çalışmada, özellikle gelişmekte olan ülkeler için uluslararası sermaye hareketlerinin olumlu etkilerinin olduğunu saptamışlardır. Kose ve diğerleri (2006) ise, finansal serbestleşmenin gelişen ülkelerde büyüme krizlerine yol açtığına ilişkin çok az sistematik kanıtın olduğu bulgusuna ulaşmıştır.

Vergil ve Karaca (2010) ise, portföy yatırımları ve doğrudan yabancı yatırımların büyüme üzerinde pozitif etkisi olduğunu tespit ederken, kısa vadeli sermaye yatırımlarının negatif bir etkiye sahip olduğunu saptamışlardır. Benzer şekilde Biçen (2017) de kısa vadeli sermaye girişlerinin büyüme üzerinde bir canlılık meydana getirerek pozitif yönde etki yarattığını vurgularken, kısa vadeli sermayenin ülkeyi terk etmesinin finansal krizlere ve durgunluğa yol açabileceğini öne sürmektedir.

Yıldırım'ın 2010 yılında yaptığı çalışmada, 2009 yılı Kasım ayı itibariyle yabancı payın \%66,50 olarak gerçekleştiğini ve yabancı fonların ülkeyi terk etmelerinin krizi daha da fazla derinleştirdiğini tespit etmiş̧ir. Örnek (2008:215) ise, kısa vadeli sermaye akımlarının kısa ve uzun vadede tasarruf yaratma sürecinde negatif etki yarattığını saptamıştır.

Şenol ve Koç'un (2018: 14) yabancı portföy girişi, makro ekonomik faktör ve borsa arasındaki ilişkiyi analiz ettikleri çalışmalarında yabancı portföy yatırımlarından Borsa İstanbul, faiz oranı ve döviz kuruna yönelik bir tepkinin olduğunu, çalışma kapsamında ele aldıkları dönem bağlamında tespit etmiştir. Ayrıca yazarlar, yabancı portföy yatırımlarında meydana gelen değişimin \%75'inin yine kendisi tarafından meydana gelen gecikmelerle açıklandığını vurgularken, değişimin \%7'sinin döviz kuru, \%4'ünün faiz oranı ve geri kalan \%4'lük kısmının da Borsa İstanbul tarafından açıklandığını saptamıştır.

Kaya (2015: 611)'nın ülke risklerinin yabancı portföy yatırımları üzerindeki etkisine yönelik olarak gerçekleştirdiği çalışmasında, finansal riskin yabancı portföy yatırımlarını olumlu yönde etkilediği tespit edilirken, politik riskin yabancı portföy yatırımlarını ise olumsuz yönde etkilediğini tespit etmiştir.

Yıldız (2017: 27-28) ise, yabancı yatırımcı fonlarının sahiplik yapısı ile hisse senetlerinin getiri oynaklı̆̆1 arasında negatif bir ilişkinin olduğunu ve piyasanın fiyat istikrarını artırdığını saptamıştır. Bunun yanı sıra, yabancı tüzel yatırımcı sahiplik oranı ile hisse senedi volatilitesi arasında herhangi bir ilişkinin olmadığını vurgulamaktadır.

Yazında, yabancı sermaye ile hisse senedi oynaklı̆̆ı arasında pozitif bir ilişkinin olduğunu ve hisse senedi düzeyinde yabancı yatırımcı oranının artmasının hisse senedi getirilerini daha oynak bir hale getirdiğini tespit eden çalışmalar da mevcuttur (Li, vd., 2011; Bae, vd., 2004; Chen, vd., 2013). Ayrıca yine ilgili yazın 
incelendiğinde, yabancı sermaye oranı ile hisse senedi getiri oynaklığı arasındaki ilişkileri ele alan çalışmaların büyük bir kısmında değişkenler arasında negatif bir ilişki olduğu saptanırken, bahse konu değişkenler arasında herhangi bir ilişkinin olmadığını öne süren çalışmaların da mevcut olduğu kaydedilmektedir (Baydaş ve Polat, 2018: 45).

\section{UYGULAMA}

\subsection{Yöntem ve Varsayımlar}

Borsa İstanbul'daki yabancı pay oranının BIST100 üzerinde yaratmış olduğu etkiyi gösterebilmek için Vektör Otoregresif Model (VAR) analiz yöntemi kullanılmıştır. Yabancı pay oranı ile BIST100 endeksi arasındaki nedensellik ilişkisini ortaya çıkarmak için ise Toda Yamamoto nedensellik analizi yapılmıştır. Her iki yönteme ilişkin sonuçlar aşağıda sunulmuştur.

\subsection{Veri Seti}

Çalışma için 01.01.2014 - 29.03.2019 tarihleri arasındaki günlük bazda BIST100 endeksinin kapanış değerleri ile aynı döneme ilişkin günlük bazda yabancı yatırımcı pay oranları kullanılmıştır. Yabancı yatırımcı pay oranları Merkezi Kayı İstanbul'dan resmi yazı ile istenmiş, endeks verileri ise https://tr.investing.com adresinden temin edilmiştir. Araştırmaya dâhil edilen endeks ve günlük yabancı pay oranlarının özet istatistiki bilgileri Tablo 1'de, görünümü ise Şekil 1'de sunulmuştur.

Tablo 1. Özet İstatistiki Bilgiler

\begin{tabular}{|ccc|}
\hline Değişkenler & BIST100 & Yabancı Pay Oranı \\
\hline $\mathrm{n}$ & 1368 & 1368 \\
Ortalama & 873.9620 & 0.679622 \\
Medyan & 835.2050 & 0.683116 \\
Maksimum & 1208.450 & 0.705081 \\
Minimum & 611.8900 & 0.647028 \\
Std.Sapma. & 135.1647 & 0.014158 \\
Çarpıklık & 0.542566 & -0.430836 \\
Basıklık & 2.429121 & 2.080267 \\
\hline
\end{tabular}

Tablo 1'e göre incelenen dönem için yabancı yatırımcı pay ortalamasının \%67,96 seviyesinde olduğu görülmektedir. Dolayısıyla BIST100'ün \%50'sinden fazlası yabancı yatırımcılardan oluşmaktadır. Yabancı yatırımcı oranındaki standart sapmanın \%1 seviyesinde olması incelenen dönemdeki yabancı pay oranındaki değişimin az olduğunun bir göstergesidir. Bu sonuca göre, yerli yatırımcı oranının azlığının beraberinde bazı riskleri de getirdiği ifade edilebilecektir.

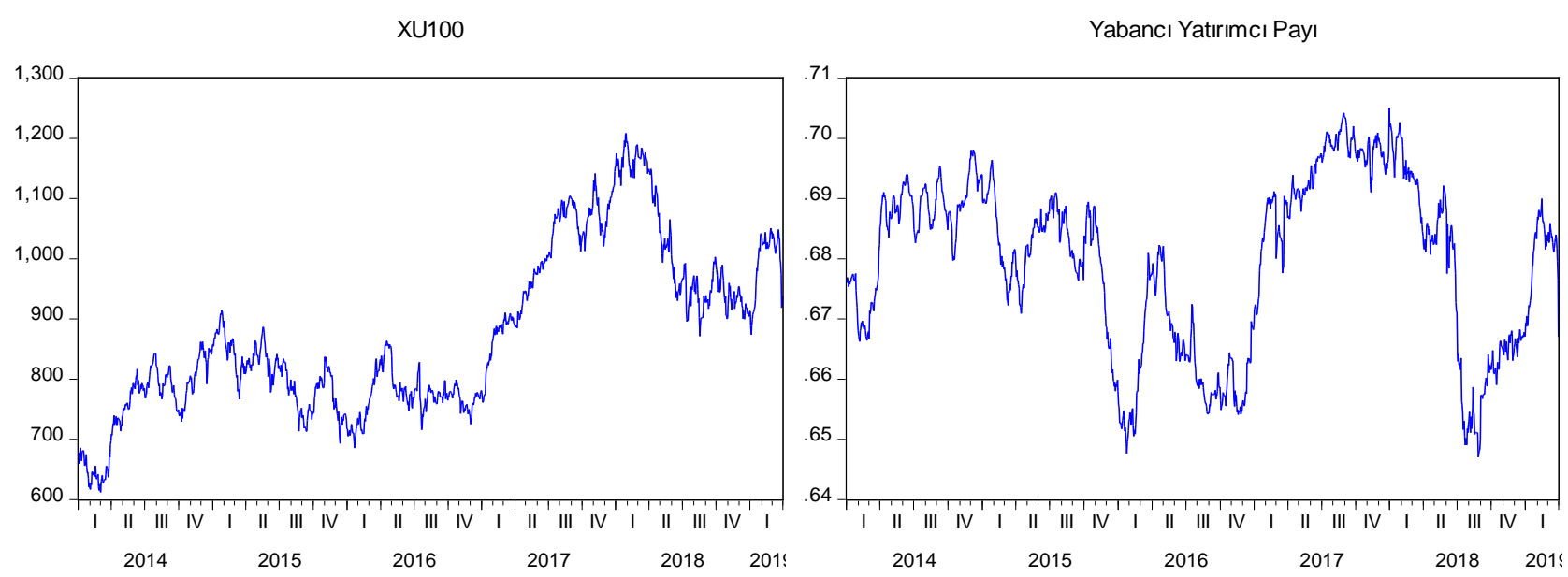

Şekil 1. BIST100 ve Yabancı Yatırımcı Pay Oranları

Şekil 1'de BIST100 ile yabancı yatırımcı oranının günlük hareketleri gösterilmektedir. İki grafik mukayese edildiğinde 2014 yılından itibaren günlük bazda BIST100 endeksi düşmeye başladığında yabancı yatırımcı oranının düşüşe geçtiği, BIST100 endeksi yükselmeye başladığında ise yabancı yatırımcı payının hızla 
yükselişe geçmeye başladığı görülmektedir. BIST100 endeksinin yükseliş veya düşüş hareketlerinde yabancı pay oranının daha sert tepkiler verdiği görülmektedir. Ancak yabancı yatırımcı çıktığı için mi BIST100 düşmekte ya da BIST100 düştügü için mi yabancı yatırımcı çıkmaktadır sorularının yanıtı aşağıdaki analizlerle belirlenecektir.

\subsection{Durağanlık ve Otokorelasyon Sınaması}

Analizde yer alan BIST100 endeksi ve yabancı pay oranları formül (1.1)'e göre günlük kapanış değerinin bir önceki kapanış değerine bölünmesi ile günlük değişimleri hesaplanmıştır. Böylelikle günlük endeks ve yabancı pay oranındaki değişimlerinin yaratmış olduğu etki tespit edilebilecektir.

$$
\left(\frac{X_{t}}{X_{t-1}}\right)
$$

Modelde yer alan değişkenlerin, birim kök içerip içermediğinin yani durağanlığının kontrol edilmesi gerekmektedir. Bunun için öncelikle yapısal kırılmaları dikkate almayan birinci nesil birim kök testleri (ADF, PP) ile değişkenlerin durağan olup olmadığına bakılmıştır. Bu çerçevede, birinci nesil birim kök nesil sonuçlarının doğruluğunu teyit etmek için seri içinde yapısal kırılmaların olup olmadığına bakılması gerekmektedir. Bunun için yapısal kırılmaları dikkate alan birim kök testleri Zivot Andrews ve ClementeMontanes-Reyes Birim Kök Testleri kullanılmıştır.

Zaman serilerinin durağan olması ise, ortalamanın ve varyansın zaman içinde değişmemesi, kovaryansın ise zamana bağlı olmayıp dönemler arasındaki gecikmeye bağlı olması durumuna atıfta bulunmaktadır. Durağanlılık durumunda serinin ortalaması, varyansı ve kovaryansı zaman içinde değişmemekte olup, bahse konu durumda seri, kendi ortalaması etrafında salınımlar göstermektedir. Yt serisinin durağanlılı̆̆1 araştırılmak istenirse, $t$ noktasından $t+k$ kadar gidildiğinde eğer $Y t$ serisi durağan ise formül (1.2)'deki $Y_{t}$, ve $\mathrm{Y}_{\mathrm{t}+\mathrm{k}}$ serilerinin ortalaması, varyansı ve kovaryansının değişmemesi aynı olması anlamına gelmektedir. Eğer seri durağan değil yani ortalaması ve varyansı zamana bağlı olarak değişiyorsa söz konusu serinin davranışının diğer dönemler için genellemesi mümkün olmayıp, gelecek için öngörüde kullanılması da mümkün olmayacaktır.

$$
\begin{array}{r}
\mathrm{E}\left(\mathrm{Y}_{\mathrm{t}}\right)=\mu \\
\operatorname{Var}\left(\mathrm{Y}_{\mathrm{t}}\right)=\gamma_{0} \\
\operatorname{Cov}\left(\mathrm{Y}_{\mathrm{t}} \mathrm{Y}_{\mathrm{t}+\mathrm{k}}\right)=\gamma_{\mathrm{k}}
\end{array}
$$

BIST100 endeksi ve yabancı yatııımcı oranı değişkenlerinin durağanlığını kontrol etmek için kullanılan birinci nesil testlerden Augmented Dickey Fuller (ADF) testi, hata terimlerinin farklı varyans ve seri korelasyon içerecek şekilde rassal ve homojen dağıldıkları varsayımını kontrol etmek için kullanılan testlerden birisidir.

$$
\Delta Y_{t}=\beta_{1}+\beta_{2} \cdot t+\delta \cdot Y_{t-1}+\alpha_{i} \cdot \sum_{i=1}^{m} \Delta Y_{t-i}+\varepsilon_{t}
$$

$\Delta \mathrm{Yt}=$ Değişkenin birinci farkı,

$\mathrm{t}=$ Trend,

$\Delta \mathrm{Y}_{\mathrm{t}-\mathrm{i}}=$ Gecikme fark1,

$\varepsilon_{t}=$ Ortalaması 0 , varyansı değişmeyen hata terimini temsil etmektedir.

Tablo 2 ve Tablo 3'te birinci nesil birim kök testleri olan ADF ve PP test sonuçları verilmiştir. 
M. Atik 12/4 (2020) 4097-4112

Tablo 2. Augmented Dickey-Fuller (ADF) Birim Kök Test Sonuçları

\begin{tabular}{|c|c|c|c|}
\hline \multirow{2}{*}{ S.Nu. } & \multirow{2}{*}{ Değişkenler } & \multicolumn{2}{|c|}{$\mathrm{I}_{0}$} \\
\hline & & Sabit & Trend + Sabit \\
\hline \multirow{4}{*}{1} & \multirow{4}{*}{ rBIST100 } & $\begin{array}{c}-36.96091 \\
(0.000)\end{array}$ & $\begin{array}{c}-36.95691 \\
(0.000)\end{array}$ \\
\hline & & $-3.434920^{* * *}$ & $-3.964767^{* * *}$ \\
\hline & & $-2.863446^{* *}$ & $-3.4413099^{* *}$ \\
\hline & & $-2.567834^{*}$ & $-3.128558^{*}$ \\
\hline \multirow{5}{*}{2} & \multirow{5}{*}{ rYabancı Pay } & -22.98514 & -22.98486 \\
\hline & & $(0.000)$ & $(0.000)$ \\
\hline & & $-3.434920^{* * *}$ & -3.964767 \\
\hline & & $-2.863446^{* *}$ & -3.413099 \\
\hline & & $-2.567834^{*}$ & -3.128558 \\
\hline
\end{tabular}

Not: ADF birim kök testi için uygun gecikme sayısı Schwarz Bilgi Kriterine göre belirlenmiştir. ${ }^{* * *}$ ve ${ }^{* * *}$ sırasıyla $0.10,0.05$ ve 0.01 için Mac-Kinnon kritik değerlerini göstermektedir. Parantez içindeki değerler testlere ait olasılık (p) değerleridir.

Tablo 3. Phillips-Perron (PP) Birim Kök Test Sonuçları

\begin{tabular}{|cccc|}
\hline \multirow{2}{*}{ S.Nu. } & Değişkenler & \multicolumn{2}{c|}{$\mathrm{I}_{0}$} \\
\cline { 3 - 4 } & & Sabit & Trend + Sabit \\
\hline \multirow{3}{*}{1} & & -36.97294 & -36.96975 \\
& rBIST100 & $(0.000)$ & $(0.000)$ \\
& & $-3.434920^{* * *}$ & $-3.964767^{* * *}$ \\
& & $-2.86446^{* *}$ & $-3.413099^{* *}$ \\
& & $-2.567834^{*}$ & $-3.128558^{*}$ \\
\hline & & -35.74992 & -35.74618 \\
& rYabanc1 Pay & $(0.000)$ & $(0.000)$ \\
& & $-3.434920^{* * *}$ & $-3.964767^{* * *}$ \\
& & $-2.863446^{* *}$ & $-3.413099^{* *}$ \\
& & $-2.567834^{*}$ & $-3.128558^{*}$ \\
\hline
\end{tabular}

Not: PP birim kök testinde tahmin metodu Bartlett Kernel kullanılmıştır. ${ }^{*}$,* ve ${ }^{* * *}$ sırasıyla 0.10, 0.05 ve 0.01 için Mac-Kinnon kritik değerlerini göstermektedir. Parantez içindeki değerler testlere ait olasıllı (p) değerleridir.

Tablo 2 ve Tablo 3'teki birinci nesil birim kök testi sonuçlarına göre değişkenlerin düzeyde durağan (Io) oldukları görülmektedir. Yapısal kırılmanın varlığı durumunda birinci nesil birim kök testleri Ho hipotezini reddetmeyerek hatalı sonuçlar verebileceği için serilerde yapısal kırılmanın varlığına da bakılmıştır. Tek kırılmayı dikkate alan Zivot-Andrews Birim Kök Test sonuçları Tablo 4'te sunulmuştur.

Şekil 1'e göre BIST100 ve yabancı yatırımcı pay hareketlerinde yapısal kırılmaların olabileceği görülmektedir. Olası bir yapısal kırılma varlığının göz ardı edilmesi durumu birim kök testlerinin sonuçlarını etkileyerek, geleneksel birinci nesil testlerin $\mathrm{H}_{0}$ hipotezinin reddedilmemesine sebebiyet verecektir (Çelik, 2016:659-660). $\mathrm{Bu}$ yüzden öncelikle tek kırılmayı dikkate alan Zivot-Andrews Birim Kök Testi yapılmış ve sonuçları Tablo 4'te sunulmuştur.

Tablo 4. Zivot-Andrews Birim Kök Test Sonuçları

\begin{tabular}{|c|c|c|c|c|c|c|c|}
\hline \multirow{2}{*}{ Değişkenler } & \multirow{2}{*}{ Model } & \multirow{2}{*}{$\begin{array}{l}\text { Kirılma } \\
\text { Dönemi }\end{array}$} & \multicolumn{3}{|c|}{ Kritik Değerler } & \multirow{2}{*}{ Min. t İstatistiği } & \multirow{2}{*}{$\mathrm{k}$} \\
\hline & & & $1 \%$ & $5 \%$ & $10 \%$ & & \\
\hline \multirow{3}{*}{ rBIST100 } & Model A & 02.12 .2016 & -5.34 & -4.8 & -4.58 & -14.780 & 6 \\
\hline & Model B & 12.06 .2017 & -4.93 & -4.42 & -4.11 & -14.657 & 6 \\
\hline & Model C & 02.12 .2016 & -5.57 & -5.08 & -4.82 & -14.817 & 6 \\
\hline \multirow{3}{*}{ rYabancı Pay } & Model A & 26.01 .2016 & -5.34 & -4.8 & -4.58 & -13.307 & 6 \\
\hline & Model B & 06.02 .2017 & -4.93 & -4.42 & -4.11 & -13.104 & 6 \\
\hline & Model C & 26.01 .2016 & -5.57 & -5.08 & -4.82 & -13.338 & 6 \\
\hline
\end{tabular}

Not: Model A, Model B ve Model C sırasıyla Sabitte, Trendde, Hem Sabitte Hem Trendde kırılmanın olduğu modelleri temsil etmektedir. $\mathrm{k}$ lag sayısını ve * simgesi $\% 5$ anlamlılık düzeyini ifade etmektedir. 
Tablo 4'deki Zivot-Andrews Birim Kök Testi sonuçlarına göre rBIST100 ve rYabancı Pay değişkenlerinin düzeyde durağan oldukları görülmektedir. Ancak yapısal kırılmanın birden fazla olması durumunda ZivotAndrews Birim Kök Test sonuçları da yanlış olabilecektir. Bunu test etmek için Tablo 5'teki iki yapısal kırılmalı birim kök testi olan Clemente-Montanes-Reyes uygulanmıştır. Bu testin en önemli avantajı yapısal kırılmaya neden olan şokun anlık olarak gerçekleşme olasıllğını (Additive Outliner-AO) ve kademeli olarak gerçekleşme (Innovation Outliner-IO) olasılığını dikkate almasıdır.

Tablo 5. Clemente-Montanes-Reyes Birim Kök Test Sonuçları

\begin{tabular}{|c|c|c|c|c|}
\hline Değişkenler & Model & t İstatistiği & Kritik Değer & $\begin{array}{l}\text { Optimal } \\
\text { Kirılma }\end{array}$ \\
\hline \multirow{2}{*}{ rBIST100 } & $\mathrm{AO}$ & -10.747 & -3.560 & 09.07 .2018 \\
\hline & IO & -17.116 & -4.270 & 10.07 .2018 \\
\hline \multirow{2}{*}{ rYabancı Pay } & $\mathrm{AO}$ & -23.590 & -3.560 & 20.03 .2017 \\
\hline & IO & -13.161 & -4.270 & 21.03 .2017 \\
\hline
\end{tabular}

Tablo 5'e göre mutlak değeri alınmış rBIST100 ve rYabanc1 Pay değişkenlerinin t-istatistik değeri, kritik değerden büyük olduğu için değişkenlerin düzeyde durağan $\left(\mathrm{I}_{0}\right)$ oldukları görülmektedir. Yapılan testler sonucunda rBIST100 ve rYabancı Pay değişkenlerinin düzeyde durağan oldukları doğrulanmıştır.

\subsection{Vektör Otoregresif Model (VAR) Analizi}

Vektör Otoregresif Model (VAR), birbiriyle etkileşim içinde oldukları düşünülen değişkenlerin içsel ve dışsal ayrımını yapmadan karşılıklı olarak etkileşimlerini ortaya çıkartmak için yapılan bir analiz türüdür: yt ve $\mathrm{zt}$ şeklinde iki zaman serisinden oluşan bir modelde, $\mathrm{y}_{\mathrm{t}}$ serisinin zaman içindeki hareketi, $\mathrm{z}_{\mathrm{t}}$ serisinin şimdiki ve geçmişteki hareketlerinden etkileniyorsa aynı şekilde $\mathrm{z}_{\mathrm{t}}$ serisinin zaman içindeki hareketi, $\mathrm{y}_{\mathrm{t}}$ serisinin şimdiki ve geçmişteki hareketlerinden etkileniyor ise model, (1.4) şeklinde kurulacaktır.

$$
\begin{aligned}
& y_{t}=\delta_{0}+\alpha_{1} \cdot y_{t-1}+y_{1} \cdot z_{t-1}+\alpha_{2} \cdot y_{t-2}+y_{2} \cdot z_{t-2}+\varepsilon_{y t} \\
& z_{t}=\omega_{0}+\beta_{1} \cdot y_{t-1}+\rho_{1} \cdot z_{t-1}+\beta_{2} \cdot y_{t-2}+\rho_{2} \cdot z_{t-2}+\varepsilon_{z t}
\end{aligned}
$$

Model (1.4)'e göre yt ve zt nin durağan oldukları ve $\varepsilon_{y t}$ ve $\varepsilon_{z t}$ 'nin ilişkisiz White noise hata terimleri olduğu varsayılmaktadır (Wooldridge, 2013:649; Barışık ve Kesikoğlu, 2003:67).

VAR analizi için değişkenlerin öncelikle gecikme uzunluklarının tespit edilmesi gerekmektedir. Gecikme uzunlukları Tablo 6'te gösterilmiştir.

Tablo 6. Bilgi Kriterlerine Göre Gecikme Uzunlukları

\begin{tabular}{|ccccccc|}
\hline Lag & LogL & LR & FPE & AIC & SC & HQ \\
\hline 0 & 10477.02 & NA & $7.66 \mathrm{e}-10$ & -15.31436 & -15.30673 & -15.31150 \\
1 & 10480.13 & 6.207281 & $7.67 \mathrm{e}-10$ & -15.31306 & -15.29016 & -15.30449 \\
2 & 10619.21 & 277.1303 & $6.29 \mathrm{e}-10$ & -15.51054 & $-15.47237^{*}$ & -15.49625 \\
3 & 10630.01 & $21.49875^{*}$ & $6.23 \mathrm{e}-10^{*}$ & $-15.52048^{*}$ & -15.46705 & $-15.50049^{*}$ \\
4 & 10633.55 & 7.036265 & $6.24 \mathrm{e}-10$ & -15.51981 & -15.45111 & -15.49410 \\
5 & 10634.58 & 2.036457 & $6.26 \mathrm{e}-10$ & -15.51547 & -15.43150 & -15.48404 \\
6 & 10635.50 & 1.825818 & $6.29 \mathrm{e}-10$ & -15.51097 & -15.41173 & -15.47383 \\
\hline
\end{tabular}

Tablo 1'e göre Likelihood Ratio (LR), Final Prediction Error (FPE), Akaike Information Criterion (AIC), Hannan-Quinn (HQ) bilgi kriterlerine göre uygun gecikme uzunluğu 3 olarak tespit edilmiştir. Seçilen gecikme uzunluğunda artıklarda otokorelasyon probleminin olup olmadığını belirleyebilmek için LM otokorelasyon testi yapılmıştır. Otokorelasyon, hata terimlerinin değerleri arasında ilişki olması durumudur. Her $t \neq s$ için $X^{\prime}$ e koşullu olup ve rassal olmayacak şekilde, iki farklı zaman dönemine ait hatalar arasında 
korelasyon olmaması gerekliliği formül (1.5)'te gösterilmektedir (Wooldridge, 2013:349). Gecikme uzunluğu için yapılan otokorelasyon test sonuçları Tablo 7'dedir.

$$
\operatorname{Corr}\left(u_{t}, u_{s} \mid X\right)=0, T u ̈ m t \neq s
$$

Tablo 7. LM Otokorelasyon Test Sonuçları

\begin{tabular}{|ccc|}
\hline Lags & LM-Stat & Prob \\
\hline 1 & 6.797614 & 0.1470 \\
2 & 2.094316 & 0.7184 \\
3 & 2.029504 & 0.7303 \\
4 & 6.025634 & 0.1972 \\
\hline
\end{tabular}

Tablo 7'deki sonuçlara göre üçüncü gecikme uzunluğunda olasılık değeri 0,05 'ten büyük olduğu için $(0,7303$ $>0,05)$ Ho red edilememekte ve söz konusu gecikme uzunluğunda otokorelasyon problemi bulunmamaktadır.

Gecikme uzunluğuna göre kurulan VAR modelinin tahmin sonuçlarının kararlı olması için hata terimlerine bakılması, durağan bir yapı gösterip göstermediğinin tespit edilmesi gerekmektedir. Modelin durağanlılığı ve istikrarlı katsayılar elde etmesi ise özdeğerlerine bağlı olarak gerçekleşmekte olup, modeldeki özdeğerlerin hepsinin birim çember içinde bulunması durumunda sistemin durağan ve istikrarlı bir yapı gösterdiği sonucuna ulaşılmaktadır.

\section{Inverse Roots of AR Characteristic Polynomial}

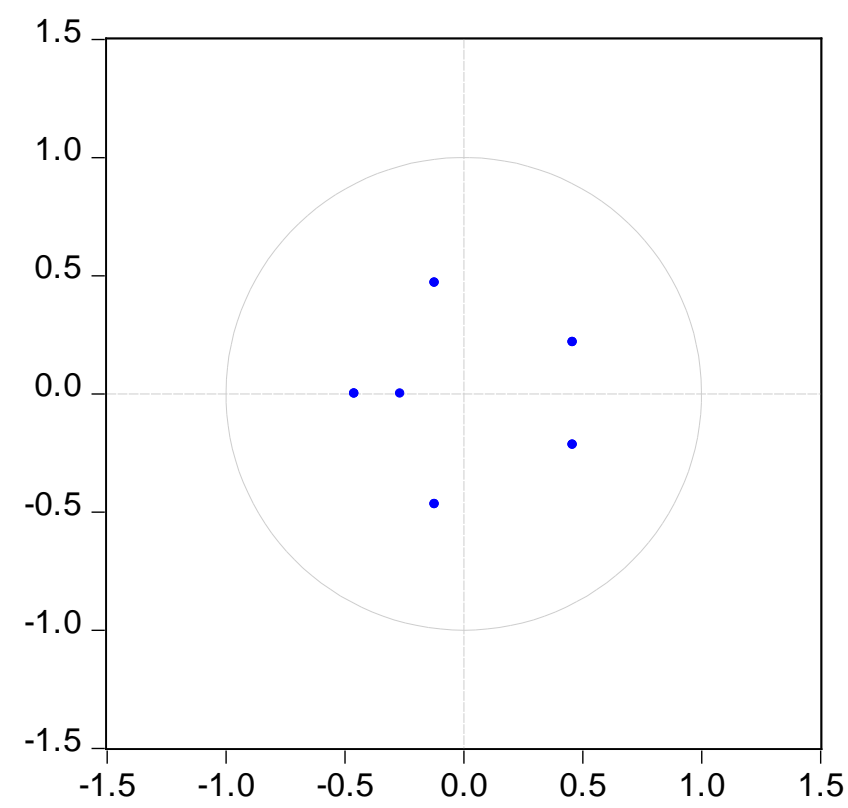

Şekil 2. AR Karakteristik Polinomunun Ters Kökleri

Şekil 2'ye göre AR Karakteristik polinomunun ters köklerinin birim çember içinde olması kurulan VAR modelinin durağan olup, katsayı değerlerinin kararlı olduğunu ve yapısal olarak bir sorun içermediğini göstermektedir.

Günlük bazdaki yabancı yatırımcı oranının BIST100 endeksi üzerindeki etkisini araştırmak için yapılan üç gecikmeli Vektör Otoregresif Model (VAR) analiz sonuçları Tablo 8'de gösterilmiştir. 
M. Atik 12/4 (2020) 4097-4112

Tablo 8. Vektör Otoregresif Model (VAR) Analiz Sonuçları

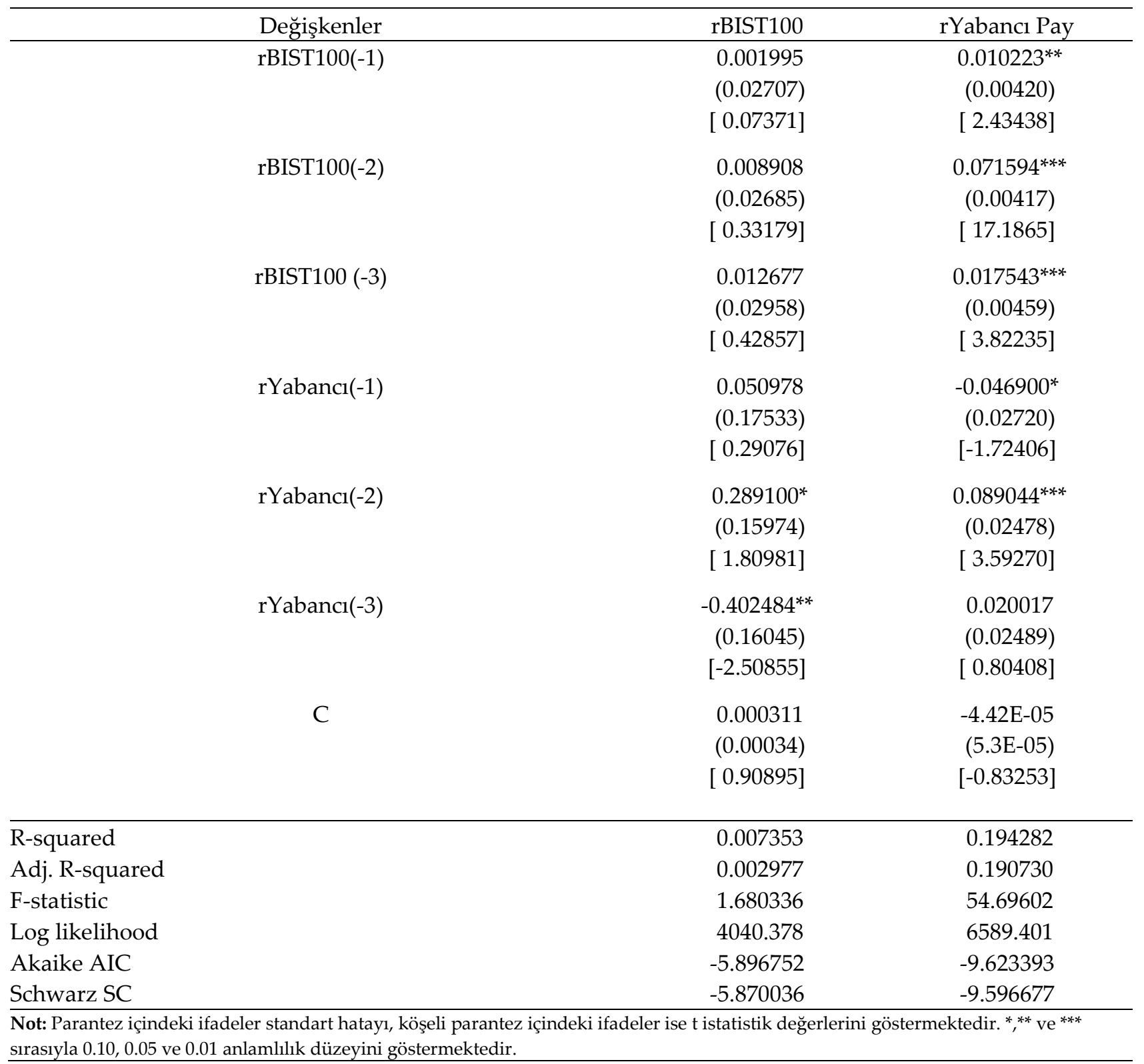

Tablo 8'deki sonuçlar incelendiğinde, bir gün gecikmeli BIST100 değerindeki bir birimlik artışın yabancı pay oranındaki değişimi anlamlı bir şekilde artırdığı (0.010223), iki gün gecikmeli BIST100 değerindeki bir birimlik artışın yabancı pay oranındaki değişimi anlamlı bir şekilde artırdığı (0.071594) ve üç gün gecikmeli BIST100 değerindeki bir birimlik artışın ise yabancı pay oranındaki değişimi yine anlamlı bir şekilde (0.017543) artırdığı tespit edilmiştir. Sonuç olarak Borsa İstanbul'da meydana gelen artışların borsadaki yabancı yatırımcı oranını pozitif etkileyerek artırdığı görülmektedir. Ancak tam tersi bir durumda BIST100 endeksinin bağımlı değişken seçilerek, yabancı yatırımcı payındaki artışın BIST100 üzerindeki etkisi incelendiğinde ise yabancı paydaki artışın BIST100'deki değişimi açılama derecesinin çok düşük olduğu görülmektedir. Üç gün gecikmeli yabancı pay oranındaki bir birimlik artışın BIST100'ü arttırmayıp, düşürdüğü (-0.402484) görülmektedir. Ancak bu kurulan VAR modelinin yabancı paydaki artışın BIST100'deki değişimi açılama derecesi çok düşüktür. VAR analizi sonuçlarına göre BIST100'deki artış yabancı yatırımcı oranını etkilerken, yabancı payındaki artışın BIST100'ü etkileme derecesinin düşük olabileceği bulgusuna ulaşılmaktadır. Dolayısıyla yabancı yatırımcı payı ile BIST100 arasında tek yönlü bir ilişki olabilecektir. Söz konusu ilişki tek taraflı gibi gözükse de tek taraflı veya çift taraflı olup olmadığını anlayabilmek için nedensellik analizlerinin yapılması gerekmektedir. 


\subsection{Etki-Tepki Analizi}

Etki-tepki fonksiyonları, rassal hata terimlerine uygulanan bir standart sapmalık şokun, içsel değişkenlerin şimdiki ve gelecekteki değerlerine olan etkisini göstermektedir. Etki-tepki analizi ile modeldeki bir değişkene uygulanacak rastgele bir şokun, modeldeki diğer değişkenler üzerinde yol açacağı etkiyi göstermesi açısından önemlidir. Değişkenlerin maruz kaldıkları şokları geçici ve kalıcı olarak iki ayrı grupta toplamak mümkündür. Kalıcı şoklar, değişkenler üzerinde uzun süre devam etmekte ve etkisi dönemler boyunca devam edecek bir karaktere sahip şoklardır. Geçici şoklar ise kalıcı bir niteliği bulunmayan ve birkaç dönem içinde etkileri yok olan şoklardır (Aktaş, 2010:128). Etki-tepki analiz sonuçları Şekil 3'te sunulmuştur.

Response to Cholesky One S.D. Innovations \pm 2 S.E.

Response ofR_XU100 to R_XU100

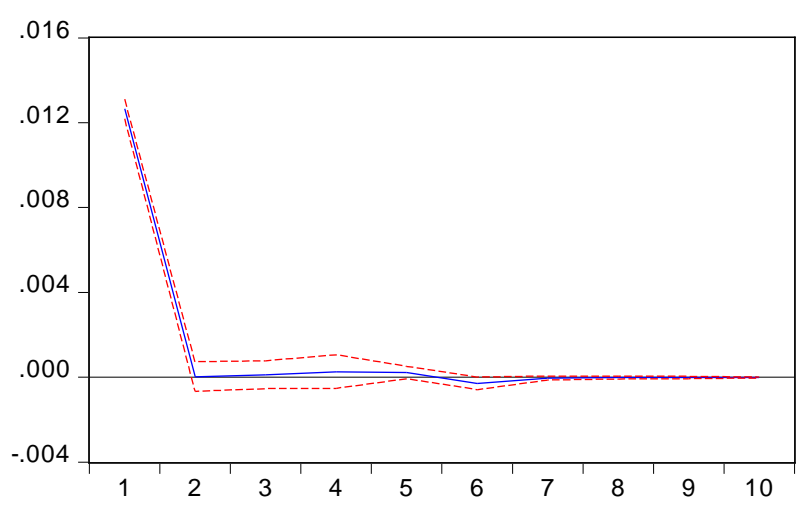

Response ofR_P_XU100 to R_XU100

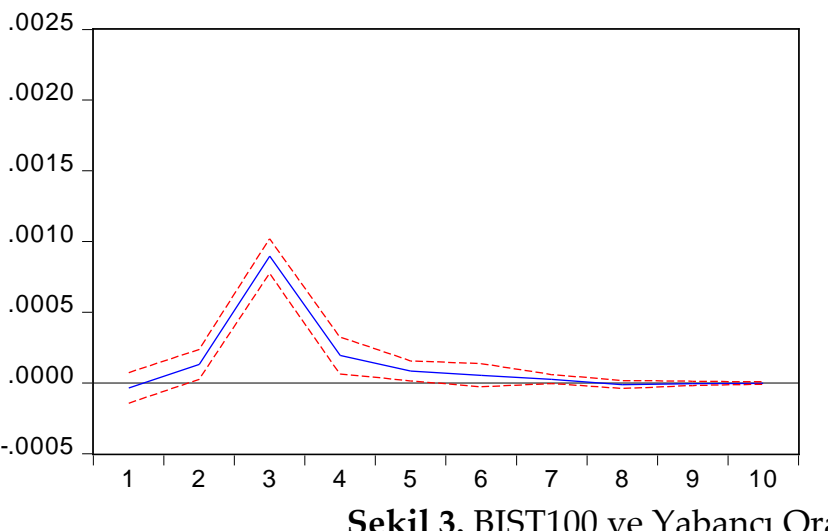

Response ofR_XU100to R_P_XU100

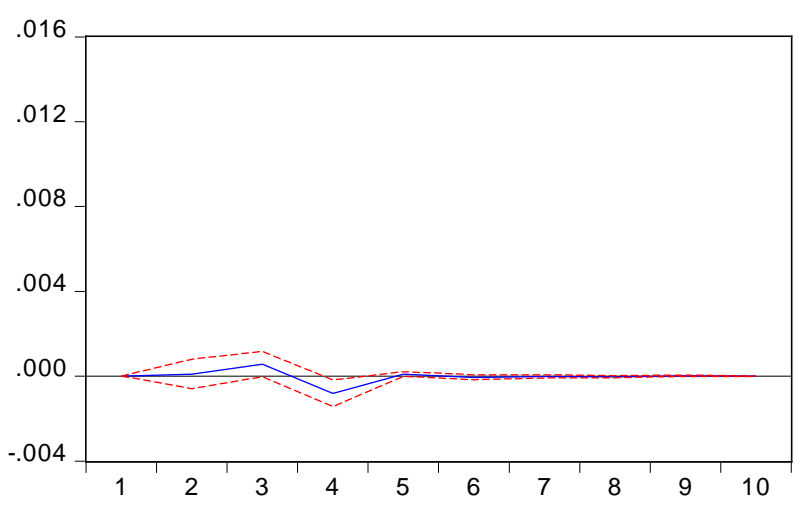

Response ofR_P_XU100 to R_P_XU100

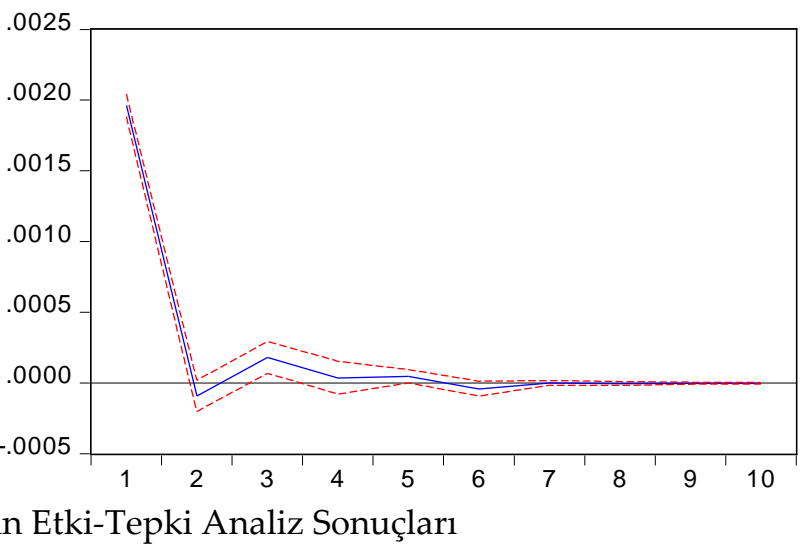

Şekil 3'teki etki-tepki fonksiyonunun güven aralıkları Monte Carlo simülasyon tekniliği ile 100 iterasyonla $\mp 2$ standart sapma aralığında üretilmiştir. Şekil 3'teki kesikli çizgiler güven aralıklarını, sürekli çizgiler ise bağımlı değişkenin bir standart sapmalık şoka karşı zaman içinde verdiği tepkiyi göstermektedir.

Şekil 3'e göre uygulanacak bir standart sapmalık şok BIST100'ü \%1,20 etkilerken, yabancı pay oranında ise $\% 0,20$ 'dir. Yabancı pay'a bir birimlik şok uygulandığında BIST100'e etkisi, ilk üç dönem artan, 3'üncü dönemden sonra azalan bir etkisi yaratarak 7'nci dönemde ortadan kaybolmaktadır. BIST100'e bir birimlik şok uygulandığında yabancı yatırımcı payına etkisi ise çok azdır.

\subsection{Varyans Ayrıştırması}

Varyans ayrıştırma, modelde kullanılan değişkenlerde meydana gelecek bir değişmenin yüzde kaçının kendisinden, yüzde kaçının diğer değişkenlerden kaynaklandığını tespit etmek için kullanılmaktadır. Tablo 9'da Yabancı yatırımcı payına ilişkin, Tablo 10'da BIST100'e ilişkin varyans ayrıştırma sonuçları verilmiştir. 
M. Atik 12/4 (2020) 4097-4112

Tablo 9. Yabancı Yatırımcı Payı İçin Varyans Ayrıştırma Sonuçları

\begin{tabular}{|c|c|c|c|}
\hline Dönem & Std.Hata & rBIST100 & rYabancı Pay \\
\hline 1 & 0.001963 & $\begin{array}{l}0.033932 \\
(0.13432)\end{array}$ & $\begin{array}{l}99.96607 \\
(0.13432)\end{array}$ \\
\hline 2 & 0.001970 & $\begin{array}{l}0.476345 \\
(0.38965)\end{array}$ & $\begin{array}{l}99.52365 \\
(0.38965)\end{array}$ \\
\hline 3 & 0.002172 & $\begin{array}{l}17.44229 \\
(1.70062)\end{array}$ & $\begin{array}{l}82.55771 \\
(1.70062)\end{array}$ \\
\hline 4 & 0.002181 & $\begin{array}{l}18.08873 \\
(1.76485)\end{array}$ & $\begin{array}{l}81.91127 \\
(1.76485)\end{array}$ \\
\hline 5 & 0.002183 & $\begin{array}{l}18.20261 \\
(1.78453)\end{array}$ & $\begin{array}{l}81.79739 \\
(1.78453)\end{array}$ \\
\hline 6 & 0.002184 & $\begin{array}{l}18.24569 \\
(1.79631)\end{array}$ & $\begin{array}{l}81.75431 \\
(1.79631)\end{array}$ \\
\hline 7 & 0.002184 & $\begin{array}{l}18.25725 \\
(1.79891)\end{array}$ & $\begin{array}{l}81.74275 \\
(1.79891)\end{array}$ \\
\hline 8 & 0.002184 & $\begin{array}{l}18.25986 \\
(1.80050)\end{array}$ & $\begin{array}{l}81.74014 \\
(1.80050)\end{array}$ \\
\hline 9 & 0.002184 & $\begin{array}{l}18.26020 \\
(1.80087)\end{array}$ & $\begin{array}{l}81.73980 \\
(1.80087)\end{array}$ \\
\hline 10 & 0.002184 & $\begin{array}{l}18.26029 \\
(1.80099)\end{array}$ & $\begin{array}{l}81.73971 \\
(1.80099)\end{array}$ \\
\hline
\end{tabular}

Tablo 9'a göre yabancı yatırımcı payında meydana gelen değişimin 3'üncü dönemden itibaren değişimin \%82,55'i kendisi \%17,44'ü ise BIST100 meydana gelen değişimler tarafından açıklanmaktadır. Dolayısıyla yabancı yatırımcı payında oluşan değişimin 3'üncü dönem itibariyle yaklaşık \%17'si BIST100'deki değişimlerden kaynaklanmaktadır.

Tablo 10. BIST100 İçin Varyans Ayrıştırma Sonuçları

\begin{tabular}{|c|c|c|c|}
\hline Dönem & Std.Hata & rBIST100 & rYabancı Pay \\
\hline 1 & 0.012653 & $\begin{array}{l}100.0000 \\
(0.00000)\end{array}$ & $\begin{array}{l}0.000000 \\
(0.00000)\end{array}$ \\
\hline 2 & 0.012653 & $\begin{array}{l}99.99375 \\
(0.08828)\end{array}$ & $\begin{array}{l}0.006254 \\
(0.08828)\end{array}$ \\
\hline 3 & 0.012666 & $\begin{array}{l}99.79621 \\
(0.24524)\end{array}$ & $\begin{array}{l}0.203785 \\
(0.24524)\end{array}$ \\
\hline 4 & 0.012695 & $\begin{array}{l}99.39457 \\
(0.40001)\end{array}$ & $\begin{array}{l}0.605435 \\
(0.40001)\end{array}$ \\
\hline 5 & 0.012697 & $\begin{array}{l}99.38911 \\
(0.40522)\end{array}$ & $\begin{array}{l}0.610893 \\
(0.40522)\end{array}$ \\
\hline 6 & 0.012700 & $\begin{array}{l}99.38724 \\
(0.40802)\end{array}$ & $\begin{array}{l}0.612756 \\
(0.40802)\end{array}$ \\
\hline 7 & 0.012700 & $\begin{array}{l}99.38716 \\
(0.40913)\end{array}$ & $\begin{array}{l}0.612844 \\
(0.40913)\end{array}$ \\
\hline 8 & 0.012701 & $\begin{array}{l}99.38659 \\
(0.41015)\end{array}$ & $\begin{array}{l}0.613407 \\
(0.41015)\end{array}$ \\
\hline 9 & 0.012701 & $\begin{array}{l}99.38645 \\
(0.41058)\end{array}$ & $\begin{array}{l}0.613554 \\
(0.41058)\end{array}$ \\
\hline 10 & 0.012701 & $\begin{array}{l}99.38645 \\
(0.41061)\end{array}$ & $\begin{array}{l}0.613554 \\
(0.41061)\end{array}$ \\
\hline
\end{tabular}

Tablo 10'a göre BIST100'de meydana gelen değişimin neredeyse tamamı kendisindeki değişimlerden kaynaklanmaktadır. Borsa'daki değişkenlikte yabancı giriş ve çıkışların etkisi olduğu yorumu yapılsa da 
sonuçlarda BIST100 endeksindeki değişim üzerinde sanılanın aksine direkt yabancı yatırımcı oranından kaynaklı bir etki görülmemektedir.

\subsection{Saklı Eşbütünleşme Analizi}

Değişkenler arasında uzun dönemli bir ilişki olmasa da değişkenler negatif $\left(\mathrm{X}^{-}\right)$ve pozitif $\left(\mathrm{X}^{+}\right)$bileşenlere ayrıldıktan sonra bahse konu bileşenler arasında ilişki olması durumunda, değişkenler arasında saklı eşbütünleşme ilişkisinden söz edilebilmektedir. Granger ve Yoon (2002) seriler arasında uzun dönemli bir ilişki bulunamamış olsa bile serilerin pozitif veya negatif bileşenleri arasında saklı eşbütünleşme ilişkisinin olabileceğini ifade etmektedir. Saklı eşbütünleme analizi doğrusal olmayan eşbütünleşme analizidir. Granger ve Yoon (2002) tarafından geliştirilen saklı eşbütünleşme testi temelde Engle ve Granger (1987) eşbütünleşme testine dayanırken, Hatemi-J ve Irandoust (2012) tarafından geliştirilen saklı eşbütünleşme testi ise temelde Johansen eşbütünleşme testine dayanmaktadır.

Saklı eşbütünleşme testini açıklamak için rassal yürüyüş sürecine sahip iki seri (1.6) gösterilmiştir (Granger ve Yoon, 2002, 6):

$$
X_{t}=X_{t-1}+\varepsilon_{t}=X_{0}+\sum_{i=1}^{t} \varepsilon_{i} \quad Y_{t}=Y_{t-1}+\delta_{t}=Y_{0}+\sum_{i=1}^{t} \delta_{i}
$$

$\mathrm{t}=1,2, \ldots ., \mathrm{T}$,

Xove $Y_{0}$ başlangiç değerleri,

$\varepsilon$ ve $\delta$ sifır ortalamalı hata terimlerini,

$\varepsilon \sim N\left(0, \sigma_{\varepsilon}^{2}\right)$ ve $\delta \sim N\left(0, \sigma_{\delta}^{2}\right)$

$\varepsilon_{i}$ ve $\delta_{i}$ serileri için pozitif ve negatif şoklar (1.7)'de tanımlanmıştır.

$$
\varepsilon_{i}^{+}=\max \left(\varepsilon_{i}, 0\right) \quad \varepsilon_{i}^{-}=\min \left(\varepsilon_{i}, 0\right) \quad \delta_{i}^{+}=\max \left(\delta_{i}, 0\right) \quad \delta_{i}^{-}=\min \left(\delta_{i}, 0\right)
$$

$\varepsilon_{i}=\varepsilon_{i}^{+}+\varepsilon_{i}^{-}$ve $\varepsilon_{i}=\varepsilon_{i}^{+}+\varepsilon_{i}^{-}$şeklinde tanımlamak mümkündür. Buna göre (1.6) tekrar düzenlendiğinde (1.8) model elde edilecektir.

$$
X_{t}=X_{t-1}+\varepsilon_{t}=X_{0}+\sum_{i=1}^{t} \varepsilon_{i}^{+}+\sum_{i=1}^{t} \varepsilon_{i}^{-}, \quad Y_{t}=Y_{t-1}+\delta_{t}=Y_{0}+\sum_{i=1}^{t} \delta_{i}^{+}+\sum_{i=1}^{t} \delta_{i}^{-}
$$

X ve $Y$ serisi için pozitif ve negatif şoklar (1.9)'daki eşitliklerle gösterilmiştir.

$$
X_{t}^{+}=\sum_{i=1}^{t} \varepsilon_{i}^{+}, \quad X_{t}^{-}=\sum_{i=1}^{t} \varepsilon_{i}^{-}, \quad Y_{t}^{+}=\sum_{i=1}^{t} \delta_{i}^{+}, \quad Y_{t}^{-}=\sum_{i=1}^{t} \delta_{i}^{-}
$$

(1.6), (1.9) göre tekrar düzenlendiğinde (1.10) elde edilecektir. 


$$
X_{t}=X_{0}+X_{t}^{+}+X_{t}^{-} \quad, \quad Y_{t}=Y_{0}+Y_{t}^{+}+Y_{t}^{-}
$$

$\Delta X_{t}^{+}=\varepsilon_{t}^{+}, \Delta X_{t}^{-}=\varepsilon_{t}^{-}, \Delta Y_{t}^{+}=\delta_{t}^{+}, \Delta Y_{t}^{-}=\delta_{t}^{-}$eşitliği geçerli olacaktır.

Hatemi-J ve Irandoust Saklı Eşbütünleşme testinden önce değişkenler negatif ve pozitif bileşenlerine ayrılarak durağanlık kontrolü için ADF ve PP birim kök testleri uygulanmıştır. Hem negatif hem de pozitif seriler düzeyde durağan olmadıkları için birinci farkları alınarak durağan hale getirilmiştir. Serilerin düzeyde durağan olmayıp, birinci farklarında I(1) durağan hale gelmeleri bileşenler arasında saklı eşbütünleşme ilişkisinin olabileceğine işaret etmektedir.

Tablo 11. Hatemi-J ve Irandoust Saklı Eşbütünleşme Test Sonuçları

\begin{tabular}{|lcccc|}
\hline Eşbütünleşme İlişkisi & Ho Hipotezi & İz İstatistiği & Özdeğer İstatistiği & Olasılık Değeri \\
\hline BIST100, YABANCI & $\mathrm{r}=0$ & 613.9835 & 0.259940 & 0.0001 \\
dBIST100-, & $\mathrm{r} \leq 1$ & 202.1818 & 0.137391 & 0.0001 \\
dYABANCI- & $\mathrm{r}=0$ & 910.1639 & 0.336078 & 0.0000 \\
dBIST100+, & $\mathrm{r} \leq 1$ & 351.4820 & 0.227161 & 0.0000 \\
dYABANCI $^{+}$ & $\mathrm{r}=0$ & 882.8578 & 0.321432 & 0.0001 \\
dBIST100-, & $\mathrm{r} \leq 1$ & 353.9380 & 0.228551 & 0.0000 \\
dYABANCI+ & $\mathrm{r}=0$ & 513.8296 & 0.201886 & 0.0001 \\
& $\mathrm{r} \leq 1$ & 206.6940 & 0.140804 & 0.0000 \\
dBIST100+, dYABANCI- & $\mathrm{r}=0$ & 637.3073 & 0.228211 & 0.0001 \\
& $\mathrm{r} \leq 1$ & 284.2302 & 0.188226 & 0.0000 \\
\hline
\end{tabular}

Johansen eşbütünleme testine dayanan Tablo 11'deki Hatemi-J ve Irandoust test sonuçlarına göre BIST100 ile Yabancı Yatırımcı Payı arasında uzun dönemli bir ilişkinin olduğu ayrıca söz konusu iki değişkenin pozitif ve negatif bileşenleri arasında da saklı uzun dönem eşbütünleşme ilişkinin varlığı tespit edilmiştir. Ayrıca BIST100'ün yükselişi (BIST100+) ile Yabancı yatırımcı payının yükselişi (Yabanci') arasında da uzun dönemde ilişki bulunmaktadır. Aynı durum her iki değişkenin düşüşü içinde geçerlidir.

\subsection{Nedensellik Analizi}

İki değişken arasında zamana bağlı gecikmeli ilişkinin belirlenebilmesi için nedensellik analizleri kullanılmakta olup bu çalışmada, Toda Yamamoto nedensellik analizi kullanılmıştır. Toda Yamamoto Nedensellik analizi, Granger nedensellik analizinden farklı olarak serilerin durağan veya aynı mertebeden entegre olması şartına ve koentegre olup olmamasına bakılmaksızın bağımsız bir şekilde analizin yapılmasını imkan tanımaktadır (Akar, 2008:189). Toda Yamamoto Nedensellik testi için kurulan model (1.11)'dedir.

$$
\begin{gathered}
\operatorname{BIST}_{\mathrm{t}}=\alpha_{0}+\sum_{\mathrm{i}=1}^{\mathrm{k}} \alpha_{1 \mathrm{i}} \mathrm{BIST}_{\mathrm{t}-\mathrm{i}}+\sum_{\mathrm{j}=\mathrm{k}+1}^{\mathrm{k}+\mathrm{d}_{\max }} \alpha_{2 \mathrm{j}} \mathrm{BIST}_{\mathrm{t}-\mathrm{j}}+\sum_{\mathrm{i}=1}^{\mathrm{k}} \emptyset_{1 \mathrm{i}} \text { Yabanci }_{\mathrm{t}-\mathrm{i}}+\sum_{\mathrm{j}=\mathrm{k}+1}^{\mathrm{k}+\mathrm{d}_{\max }} \emptyset_{2 \mathrm{j}} \text { Yabanci }_{\mathrm{t}-\mathrm{j}}+\varepsilon_{1 \mathrm{t}} \\
\text { Yabanci }_{\mathrm{t}}=\beta_{0}+\sum_{\mathrm{i}=1}^{\mathrm{k}} \beta_{1 \mathrm{i}} \text { Yabanci }_{\mathrm{t}-\mathrm{i}}+\sum_{\mathrm{j}=\mathrm{k}+1}^{\mathrm{k}+\mathrm{d}_{\max }} \alpha_{2 \mathrm{j}} \text { Yabanci }_{\mathrm{t}-\mathrm{j}}+\sum_{\mathrm{i}=1}^{\mathrm{k}} \delta_{1 \mathrm{i}} \mathrm{BIST}_{\mathrm{t}-\mathrm{i}}+\sum_{\mathrm{j}=\mathrm{k}+1}^{\mathrm{k}+\mathrm{d}_{\text {max }}} \delta_{2 \mathrm{j}} \mathrm{BIST}_{\mathrm{t}-\mathrm{j}}+\varepsilon_{2 \mathrm{t}}
\end{gathered}
$$


Toda Yamamoto nedensellik testi modifiye edilmiş WALD yardımıyla gerçekleştirilmiştir. $\emptyset_{1 i}=0$ hipotezi reddedildiğinde yabancı pay oranından BIST100 endeksine doğru, $\delta_{1 i}=0$ hipotezi reddedildiğinde de BIST100'den yabancı pay oranına doğru nedensellik ilişkisinin olduğunu göstermektedir. Toda Yamamoto nedensellik testi sonuçları Tablo 12 'dedir.

Tablo 12. Toda Yamamoto Nedensellik Testi Sonuçları

\begin{tabular}{|c|c|c|c|}
\hline \multirow{2}{*}{ Bağımlı Değişken } & \multicolumn{2}{|c|}{ MWALD İstatistikleri } & \multirow{2}{*}{ Nedenselliğin Yönü } \\
\hline & BIST100 & Yabanc1 & \\
\hline BIST100 & - & $\begin{array}{c}9.457 \\
(0.023)\end{array}$ & Yabancı BIST100 \\
\hline Yabanc1 & $\begin{array}{c}312.159 \\
(0,000)\end{array}$ & - & BIST100 Yabanc1 \\
\hline
\end{tabular}

Tablo 12'deki sonuçlara göre BIST100 ile yabancı pay oranı arasında çift yönlü bir nedensellik ilişkisinin bulunmaktadır. Bu durum BIST100'deki değişim sonucu yabancı yatırımcıların etkilenerek BIST100'de işlem yaptıklarını ve yabancı yatırımcılardaki değişim sonucu BIST100'ün değiştiği bilgisine ulaşılmaktadır.

\section{SONUÇ}

Gelişmekte olan ülkelerde yurt içi tasarrufların yeterli boyutlarda olmaması durumunun ekonomik büyümenin önündeki engellerden birisini oluşturduğu söylenebilecek olup, bahse konu ülkelerin bu açıklarını kapatarak ekonomik büyüme ve kalkınmalarını sağlayabilmek için ise yabancı kaynaklara başvurdukları değerlendirilmektedir. Bahse konu durum ise, ülkelerin finansal piyasalarına uluslararası sermaye akımlarının girmesine ve ekonomilerinin etkilenmesine yol açmaktadır.

İlgili yazında, uluslararası sermaye akımlarının piyasalarda olumlu etkiler sağladığına ilişkin görüş ve çalışmaların olmasının yanı sıra, tam tersi görüşlerin de bulunduğu kaydedilmektedir. Anılan durumun sebebi ise, uluslararası sermaye akımlarının büyüme için gerekli olan sermaye, bilgi ve teknolojiyi sağlamasına karşın herhangi bir kriz durumunda ani çıkışların yaşanması ve bu durumun da piyasaları daha kırılgan bir hale getirmesi olduğu değerlendirilmektedir. Ülke piyasasının farklılığı sermaye piyasalarına yatırım yapan yatırımcıları farklılaştırmaktadır. Bu çalışmada Borsa İstanbul'daki yabancı yatırımcı oranının BIST100 endeksi üzerindeki etkisi incelenmiştir. Türkiye'de yabancı yatırımcıların oranın, çalışma bağlamında incelenen dönem için ortalama \%67 gibi yüksek bir oranda olması durumunun, yabancı payının sermaye piyasalar üzerindeki etkisinin doğru analiz edilebilmesi ve ekonomiye etkilerinin doğru değerlendirilebilmesi açısından önem arz ettiği söylenebilecektir.

Yapılan analiz sonuçlarına göre BIST100 ve yabancı pay oranı arasında çift yönlü bir nedensellik ilişkisi bulunmuştur. Bu bağlamda, BIST100'deki değişim yabancı yatırımcı oranını etkilerken, yabancı payındaki değişim de BIST100'ü etkilemektedir. BIST100'deki artış sonucunda yabancı yatırımcıların işlem yaptıkları görülmektedir. Ayrıca her iki değişken yükselişte ve düşüşte uzun dönemli bir ilişkiye sahiptir. Yabancı yatırımcı payında oluşan değişimin 3'üncü dönem itibariyle yaklaşı \%17,44'ü BIST100'deki değişimlerden kaynaklanırken, BIST100'de meydana gelen değişimin neredeyse tamamı kendi iç dinamiklerinden kaynaklanmaktadır. BIST100'deki değişkenlikte yabancıların payı olduğu yorumu yapılsa da incelenen dönem için yapılan analiz sonuçlarına göre BIST100 endeksindeki değişimin sanılanın aksine yabancı yatırımcıdan kaynaklı olmadığı değerlendirilmektedir. Çalışma sonucunda bulunan sonuçlar yazındaki diğer çalışma sonuçları ile örtüşse de özellikle yabancı paydaki değişimin BIST100 endeksindeki değişimi tam olarak açıklayamamaktadır. Bu tespit BIST100'ü etkileyen çok sayıda faktörün olduğunun göstergesi niteliğindedir. Gelecekte yapılacak çalışmalarda ise yabancı paydaki değişimin Mali, Teknik, Sanayi gibi sektör bazlı endekslerdeki etkisinin incelenmesi ve aynı etkilerin görülüp görülmeyeceği konusunun araştırılmasının uygun olabileceği değerlendirilmektedir 


\section{KAYNAKÇA}

Adabag, M.C. and Ornelas, J.R.H. (2004). Behavior and Effects of Foreign Investors on Istanbul Stock Exchange, SSRN Electronic Journal, 4.

Akar, C. (2008). Hisse Senedi Fiyatlarıyla Yabancı İşlem Hacmi Arasında Nedensellik: Toda-Yamamoto Yaklaşımı, Sayı 37, 189.

Aktaş, C. (2010). Türkiye' de Reel Döviz Kuru İle İhracat ve İthalat Arasındaki İlişkinin Var Tekniğiyle Analizi, ZKÜ Sosyal Bilimler Dergisi, 6 (11), 123-140.

Bae, K.H., Chan, K., Ng, A. (2004). Investibility and Return Volatility. Journal of Financial Economics, 71(2), 239-263.

Barışık, S. ve Kesikoğlu, F. (2003). Türkiye'de Bütçe Açıklarının Temel Makroekonomik Değişkenler Üzerine Etkisi (1987-2003 VAR, Etki-Tepki Analizi, Varyans Aynştırması, Ankara Üniversitesi SBF Dergisi, 61(4), 67.

Baydaş, Y. ve Polat, M. (2018). Doğrudan Yabancı Sermaye Yatırımlarının Borsa İstanbul'a Etkisinin Belirlenmesi, Bingöl Üniversitesi İktisadi ve İdari Bilimler Fakültesi Dergisi, 2(2) , 37-46.

Bekaert, G., Harvey, C. R., Lundblad, C. (2005). Does Financial Liberalization Spur Growth?, Journal of Financial Economics, 77(1), 3-55.

Biçen, Ö.F. (2017). Kısa Vadeli Yabancı Sermaye Akımları Ve Ekonomik Büyüme: Yükselen Piyasa Ekonomileri Üzerine Bir İnceleme, Balıkesir Üniversitesi Sosyal Bilimler Enstitüsü Dergisi, 20(38), 97116.

Chen, Z., Du, J., Li, D., Ouyang, R. (2013). Does Foreign Institutional Ownership Increase Return Volatility? Evidence from China. Journal of Banking Finance, 37(2), 660-669.

Çiftçi, H. (2015). Doğrudan Yabancı Sermaye Yatırım İkliminin Oluşturulmasını Belirleyen Faktörler, Çukurova Üniversitesi İ̈BF Dergisi, 19(2), 174.

Edison, H. J., Klein, M.W., Ricci, L.A., Sloek, T. (2002). Capital Account Liberalization and Economic Performance: Survey and Synthesis, IMF Staff Papers, Palgrave Macmillan Journals, 51(2).

Ekodialog, (2020). Uluslararası Sermaye Hareketleri, https://www.ekodialog.com/Makaleler/uluslararasisermaye-hareketleri.html (Erişim Tarihi: 04 Haziran 2020).

Engle, R.F., Granger, C.W.J. (1987). Cointegrationand Error Correction: Representation, Estimation, and Testing, Econometrica, 55(2), 251-276.

Granger, C.W.J. and Yoon, G. (2002), Hidden cointegration, Department of Economics Working Paper.

Hatemi-J, A. and Irandoust, M., (2012), Asymmetric Interaction Between Government Spending and Terms of Trade Volatility New Evidence from Hidden Cointegration Technique, Journal of Economic Studies, 39(3), 368-378.

Kaya, E. (2015). Ülke Riskinin Yabancı Portfoy Yatırımları Üzerindeki Etkisi, İktisadi ve İdari Bilimler Dergisi, 29(4), 611.

Kose, M.A., Prasad, E., Rogoff, K., Wei, S. J. (2006). Financial Globalization: A Reappraisal, IMF Working Paper, $\mathrm{WP} / 06 / 189$.

Kula, F. (2003).Uluslararası Sermaye Hareketlerinin Etkinliği: Türkiye Üzerine Gözlemler, C.Ü. İktisadi ve İdari Bilimler Dergisi, 4(2), 143.

Li, D., Nguyen, Q. N., Pham, P.K., Wei, S.X. (2011). Large Foreign Ownership and Firm-Level Stock Return Volatility in Emerging Markets, The Journal of Financial and Quantitative Analysis, 46(4), 1127-1155.

Örnek, İ. (2008). Yabancı Sermaye Akımlarının Yurtiçi Tasarruf ve Ekonomik Büyüme Üzerine Etkisi: Türkiye Örneği, Ankara Üniversitesi SBF Dergisi, 63(2), 215. 
Şenol, Z. ve Koç, S. (2018). Yabancı Portföy Yatırımları, Borsa ve Makroekonomik Değişkenler Arası İlişkilerin VAR Yöntemiyle Analizi: Türkiye Örneği, UïïiD-IJEAS, (21),14.

Vergil, H. ve Karaca, C. (2010). Gelişmekte Olan Ülkelere Yönelik Uluslararası Sermaye Hareketlerinin Ekonomik Büyüme Üzerindeki Etkisi: Panel Veri Analizi, Ege Akademik Bakış, 10(4), 1207-1216.

Wooldridge, J.M. (2013). Introductory Econometrics (Çev. Ebru Çağlayan), Nobel Akademik Yayıncılık, 649.

Yeboua, K.(2019). Foreign Direct Investment, Financial Development and Economic Growth In Africa: Evidence From Threshold Modeling, Transnational Corporations Review, 11(3).

Yıldırım, S. (2010). 2008 Yılı Küresel Ekonomi Krizinin Dünya ve Türkiye Ekonomisine Etkileri, KMÜ Sosyal ve Ekonomik Araştırmalar Dergisi, 12(18), 49.

Yıldız, Y. (2017). Yabancı Sermaye ve Hisse Senedi Getiri Oynaklı̆̆ı: Borsa İstanbul Üzerine Bir İnceleme, İşletme Araştırmaları Dergisi, 9(4), 27-28. 